\title{
Theofilos
}

A Nordic open access journal in Theology, Philosophy and Culture

Published by NLA University College - in partnership with Johannelund School of Theology

Available at www.theofilos.no

\section{The Place of Imaginative Literature in the Christian Life}

\author{
Karen Swallow Prior \\ Research Professor of English and Christianity and Culture \\ Southeastern Baptist Theological Seminary, Wake Forest, NC \\ kprior@sebts.edu
}

We have more leisure time today than in any period in history. We also have more options for spending that leisure time. For most people (unless you are an English professor, like me), reading fiction is easily seen as purely a leisure activity. And for many, watching sports, streaming movies, or scrolling Twitter seem like more relaxing, less demanding ways to fill non-working hours. Adding the reading of fiction to already overscheduled and overthinking lives can seem frivolous in a world of hurry, need, and stress. Even the Christian who is an avid reader can be tempted to view time spent on imaginative literature as taking away from more important material such as Scripture, theology, and history. Yet, fiction - and here I will be talking primarily of literary fiction - has much to offer the Christian.

Reading fiction is a pleasure to be enjoyed for its own sake, of course. Like all fine pleasures, quality fiction is an acquired taste that is developed through exposure, intentionality, and practice. But fiction can be enjoyed even more within the understanding that all good stories reflect the ways of our Creator and the world he created. Good stories always, in some way, even if obliquely, reflect the pattern of the biblical narrative: creation, fall, redemption, and restoration.

Notably, the rise of modern fiction, particularly the novel form that arose in the early eighteenth century, is deeply tied to the Protestant Reformation. Some developments coming out of the Reformation emphasized subjective experience over and against tradition (including the authority of the Roman Church). These developments gave rise to the experiential and experimental spirits that birthed the Enlightenment and cultivated skepticism toward institutional religion and institutionalized authorities. Following excessive abuses of authority, a spirit of testing emerged - not only the testing associated with the scientific method, but also that associated with the perseverance required of the individual soul during the trials of sanctification offered by the earthly journey. Amid this transition from the premodern age to the modern age, a sharper distinction also began to emerge between nonfiction and fiction. In an era in which new scientific methods were ferreting out old superstitions, early Protestants - the Puritans in particular - understandably became suspicious of fiction, viewing it as at best, a waste of time and at worst, a lie.

Human creativity is irrepressible, however, and in their zeal against fiction, the Puritans cultivated other forms of imaginative literature that have had an immense influence on literary and cultural history. Their contributions include Christian epic (John Milton), allegory (John Bunyan), journalism (Daniel Defoe), captivity narrative (Mary Rowlandson), and spiritual autobiography (John Bunyan, along 
with many others). However, in one of literary history's great ironies, these writers and the genres they developed contributed to the rise of the novel, the genre that gave voice to the modern individual, a newly autonomous self responsible for undergoing his own spiritual birth and for finding his own meaning and place in the world.

Both science and the novel center on the subjectivity of our experience within the created order. In his account of the origins of the novel (in a book titled The Decline of the Novel), Joseph Bottum explains,

The novel came into being to present the Protestant story of the individual soul as it strove to understand its salvation and achieve its sanctification, illustrated by the parallel journey of the new-style characters, with their well-furnished interiors as they wandered through their adventures in the exterior world. ${ }^{1}$

The parallel rise of science and the novel might seem counterintuitive. These are, after all, fields that have in more modern times been set against one another. But it was not and need not be so. In a 2019 talk given at the Frankfurt Book Fair, the Norwegian fiction writer Karl Ove Knausgaard noted the connection between these two seemingly opposed ways of knowing: "Science and literature alike are readers of the world. And, sooner or later, both lead us to the unreadable, the boundary at which the unintelligible begins."2 While Knausgaard does not say it, I will: the "unintelligible" is a way of gesturing toward God.

The new centrality of the individual that was at the heart of certain developments of the Protestant Reformation manifested in countless world-changing ways. For example, the doctrine of sola scriptura necessitated not only the availability of the Bible to individuals (which the printing press made possible) but also the ability to read. The spread of literacy and printed material spurred by the Reformation not only made reading possible for more people, but it also cultivated a robust spirit of interpretation - one that contrasted dramatically with the mediating interpretation of the priests. Fiction, ultimately, is the outward expression of the inward experience of an ordinary individual making sense of (reading and interpreting) the world and his or her place in it for him or herself. The novel, as a long form of fiction written by and about ordinary people in everyday prose, embodies all these emphases of the Reformation. The novel protests the tyranny of institutional and traditional authority. Notably, the word novel also means "new." The novel truly was a new form, telling new stories (rather than retelling old stories of myth and legend) for a new era, and was understood to be such at the time. Thus, the modern novel developed as an expression of a sense of personal agency never before known in human history.

Yet, the Reformation and the imaginative literature it spawned merely advanced a trajectory set in motion by God himself according to his original plan for human beings as creatures of language and story. In a 1970 interview (published in The Medium and the Light: Reflections on Religion and Media), the famous communication theorist Marshall McLuhan offered a keen insight into the connection between the time and place of Christ's incarnation and the centrality of private identity to Christian belief:

I don't think it was accidental that Christianity began in the Greco- 
Roman culture. I don't think that Christ would have suffered under Genghis Khan with the same meaning as under Pontius Pilate. The Greeks had invented a medium, the phonetic alphabet, which, as Eric Havelock explains in his book Preface to Plato, made it possible for men to have for the first time in history a sense of private identity. A sense of private substantial identity - a self - is to this day utterly unknown to tribal societies. Christianity was introduced into a matrix of culture in which the individual had enormous significance: this is not characteristic of other world cultures. $^{3}$

First with the alphabet and later the printing press, the ancient stories and tales retold orally in communal settings around the fire were eventually replaced by printed works, composed and read by individuals. Parallels can be drawn here to certain Protestant developments that understood the Christian life as the inner, individual journey of salvation and sanctification in contrast to the communal sense of salvation taught by the Catholic Church.

Of course, most of history, including literary history, is a pendulum swing from one extreme followed by another. The sharp national decline in reading fiction reported over the past decade 4 is, in some ways, seventeenth-century history repeating itself. We may have less noble reasons than the Puritans had for disdaining novels and short stories, but the obstacles likely owe, similarly, more to cultural climate and pressures than to personal intention. We would do well to heed the lament of Sven Birkerts in his introduction to the 2006 edition of The Gutenberg Elegies (originally published in 1994):
The triumph of the digital seems also to have brought the triumph of the factual. As literature, the idea of literature, suffers depreciation, it gets ever harder to make the case for imagination. And what is imagination if not the animating power of inwardness? 5

Certainly, modern life makes the distinction between fact and fiction both desirable and necessary (the phenomenon of "fake news" being perhaps the best evidence of this). Yet, there is wisdom in the words commonly attributed to Pablo Picasso: "Art is a lie that makes us realize truth." Perhaps reading more fiction can equip us to better distinguish fact from lie because good stories told well attune us to the ring of truth. Good stories can attune us to truth in two ways.

First, literature primes us for truth simply by using the medium of language. Only through language do we think abstractly, affirm what is true, and deny what is false. The more fluent we are with language, the better able we are to understand and detect its uses, abuses, and distortions, and to make truth-claims. This is the reason George Orwell depicted the totalitarian regime in his novel 1984 as seizing control of the people by vastly reducing the words in the language. The fewer words we have, the fewer distinctions we can make. Consider, for example, the vast psychological, sociological, theological, and emotional harm done in the simple fact that English uses the word love for so many different meanings. Language - the medium of all literature, including the Bible - in and of itself illuminates and magnifies the image of God in us. Because human beings are made in the image of the one who is the Word and who spoke the world into existence through his word, cultivating our under- 
standing of the gift of language illuminates the one whose image we bear. This is evidenced by the first assignment God gave Adam in the garden: naming the animals. Through language human beings identify, interpret, and name, thereby glorifying God by reflecting his image in us. As Boris Pasternak expresses it in Doctor Zhivago, we are "here on earth to grasp the meaning of its wild enchantment and to call each thing by its right name."6 Furthermore, the "acts of naming" by literary writers and "our acts of reading cannot but conjure the possibilities of transcendence," argues theologian Graham Ward in explaining how literature by its very nature "resists secularity."7

Literary language - the artfully arranged words found in poetry, drama, creative nonfiction, and fiction - uses language in a more condensed way than everyday language. It thus cultivates skill in using and understanding all language. Regular reading of the dense language of poetry, for example, increases facility with ordinary language in the same way that running occasional sprints helps to improve the performance of a long-distance runner. If the written word were topography, literary language would form an undulating landscape of mountains, forests, and valleys. To traverse it regularly would render the smooth, flat ground of more utilitarian prose into an effortless stroll.

Likewise, literary fiction differs from commercial fiction in using the medium of language not merely to entertain, but to recreate artistically a human experience, in much the same way as a painter uses paint not simply to offer a replica, but a recreation of its subject. No one goes to a museum to see what a bowl of fruit looks like. We go to museums to see how a talented artist uses paint, color, light, canvas, and brush to show us something about a bowl of fruit that we likely wouldn't have noticed otherwise. Unlike a painting, which is revealed in space, a narrative is revealed in time and unfolds one word at a time.

Second, by taking the form of narrative, fiction practices - and allows the reader to practice - the narrative mode by which we process all our thoughts and experiences, enriching and deepening the same analytical and interpretive skills we use in everyday real life. Narrative - story - is the mode through which we process all our experiences. Every day, all day long, we interpret our own actions, the actions of others, events, our perceptions, and our very place in the world narratively: That was so nice of her. I shouldn't have done that. I need to call Mom tonight. I'm so glad I ran into him. This was a stressful day. Maybe we can just order pizza tonight. In the beginning, God created the heavens and the earth. Even such small narratives as these provide practice in identifying cause and effect, selecting and omitting details, interpreting meaning, and coming to a conclusion - processes upon which all stories are based.

The gospel, too, takes the form of a narrative: Jesus Christ was born, was crucified for our sin, rose again, lives now in heaven, and will return one day to establish a new heaven and earth. Notably, the word gospel was an Old English word that combined the words good and spell. We use the word spell today (as then) in a variety of ways: as a verb meaning to recount or to recite letter by letter; or as a noun to refer to an incantation, retelling, or story. Thus, in Old English, "gospel" simply meant "good story."

Of course, some stories are factual ("He pulled right out in front of me, officer!"), and some are derived from human 
imagination ("It was the best of times, it was the worst of times, it was the age of wisdom, it was the age of foolishness ...”). Both kinds of stories - fact and fiction, true and false - can be good, or they can be bad. The gospel story is both good and true - the best and truest story ever told. Every other good story that reveals truth does so only because of the logos at the center of the gospel.

The short etymological history above calls attention to the distinction we now make between true stories and imaginative ones. Indeed, the modern English word gospel is usually translated (from Latin through Greek) as "good news," in part to emphasize the true nature of the message. But news stories take a form opposite that of fictional ones that reveal themselves through the progression of narrative. News stories use an inverted pyramid, with the most essential facts at the top (who, what, where, when), with additional details added on as advertising space allows (and cut by editors as it does not).

But because fiction reveals its meaning and significance one word at a time, the reader's perspective is enlarged and altered as the story unfolds. In fact, the way a story is narrated is, especially in the case of literary fiction, more important than the events narrated. This is why a Wikipedia or Spark Notes summary of a work of literature can never recreate the experience of reading the actual work. When we read an imaginative work, we enter the mind and perspective of the fictional narrator and experience the unfolding of the story through the eyes of another. This is true whether the point of view is that of a third-person objective narrator or first-person limited narrator - or any combination of these. To read Vladimir Nabokov, for example, is to enter deeply into the narrow perspective of the odd criminals and misfits who populate his novels. In contrast, to read Charles Dickens is to experience the varied, refracted voices of a multitude of perspectives packed into one less-than-unified narrative voice.

When readers engage in what the English Romantic poet and critic Samuel T. Coleridge (who, by the end of his life, had become an orthodox believer) called the "willing suspension of disbelief," we allow ourselves to enter into the world of a story as it unfolds. Even so, we do not entirely leave the world of reality and judgment. Indeed, understanding good fiction depends on our ability to both understand the perspective of the narrator and judge the narrator's unavoidable biases, misperceptions, and errors as they also unfold.

Emily Ediger, a classic literature lover I know, illustrated this idea when she posted a comment on her Instagram account about her experience of reading the nineteenth-century fictional saga Middlemarch by George Eliot for the first time:

The book follows multiple characters in the town of Middlemarch as they go through day to day life and face decisions and difficulties concerning love/marriage, wealth, status, and work. I thought it was so interesting to see how each character developed and reacted to moral dilemmas. As the reader, I felt the tension of wanting them to do what would seemingly make them happy and wanting them to do what was right.

As this response demonstrates, good stories require us both to enter the mind of the one narrating and, paradoxically, to stand outside and judge the teller's perspective against reality. Not all narrators are reliable, and every narrator is fallible. Indeed, the good storyteller depends on 
the reader's ability to judge well in order to interpret the story's meaning. Reading a story well is practice for our real lives where understanding does not always mean agreement. (Nor, unfortunately, does agreement always mean understanding.)

Our experience of attending to a narrator is, in some ways, akin to listening to a friend, or perhaps even a stranger, share a story, experience, or problem. We pay attention. We seek to understand. We have compassion. We weigh. We consider. We evaluate (even if we don't voice our conclusion). In other words, we receive a person and her story, much in the same way that C. S. Lewis says in An Experiment in Criticism that we should receive art rather than use it: "'Using' is inferior to 'reception' because art, if used rather than received, merely facilitates, brightens, relieves or palliates our life, and does not add to it." 8 The stories others share with us shape and enlarge our understanding of the world and ourselves forever. In employing both narrative and the artistry of language, literary fiction surely demands something of us that much other forms of reading and entertainment do not. Among these are patience, attention, and time. So much of what we read today whether on social media, in newspapers, or emails - cultivates the habit of skimming quickly in order to gain the most necessary information that we have forgotten (if we ever even knew) how to read good works well. Like anything else, reading well takes practice. It also takes a conscientious effort simply to slow down in order to pay attention not only to what happens but to how what happens is told.

In the same speech cited above, Knausgaard addresses the "slowness" of literature, which he calls "one of literature's most important characteristics." By slowness, Knausgaard does not merely mean the length of time it can take to read a literary work (although that aspect should certainly figure in). He explains,

I'm not thinking of how long its effects can be felt, and of the strange phenomenon that even literature written in other times, on the basis of assumptions radically different to our own and, occasionally, hugely alien to us, can continue to speak to us - and, not only that, but can tell us something about who we are, something that we would not have seen otherwise, or would have seen differently ... Literature works slowly not just in history but also in the individual reader. ${ }^{9}$

Reading literary fiction requires slowness and attentiveness, and in turn gives those gifts back to us by deepening those habits and abilities in us. A great deal has been written over the past several years about what researchers across a range of disciplines call the "attention economy." Within a consumerist, throw-away culture driven by digital media, our attention is one of the most valuable commodities there is. In addition to those things in our lives we have created and instituted that rightly demand our time and attention families, church, work, communities - we are inundated daily at every literal and figurative turn with invitations and temptations to click, post, like, share, and buy at the mere flick of a finger. We can use settings, apps, and controls to try to limit the attention we give in these mediums. But the fact that we need such tricks and strategies suggests that we have already lost the game. In a 2013 essay in the London Review of Books, writer Rebecca Solnit observed,

Nearly everyone I know feels that some quality of concentration they 
once possessed has been destroyed. Reading books has become hard; the mind keeps wanting to shift from whatever it is paying attention to to pay attention to something else. A restlessness has seized hold of many of us, a sense that we should be doing something else, no matter what we are doing, or doing at least two things at once, or going to check some other medium. It's an anxiety about keeping up, about not being left out or getting behind. 10

Books - which have been around now in the form of printed pages bound in such a way that they can be held in our hands for half a millennium - can train and deepen our attentions with delightful simplicity and power. There may be nothing more countercultural than a book (unless it is a people of the Book). Indeed, Sven Birkerts declares that "for a host of reasons the bound book is the ideal vehicle for the written word." Indeed, he writes, "As the world hurtles on toward its mysterious rendezvous, the old act of slowly reading a serious book becomes an elegiac exercise." 11 It is also a life-giving exercise.

Literature cultivates within attentive readers the virtues that oppose the vices propagated by social media feeds, hot takes, and Instagram's disappearing “stories" (what a misnomer, if ever there was one!). In contrast to these, literary fiction replicates the process described in Psalm 119:130, which says, "The unfolding of your word gives light; it gives understanding to the simple." The slowness of a good story well read and well told imitates the unfolding of the truest and best story ever told, one that continues to be told in our time.

In making his case for pastors to read literary works as part of their vocation, Cornelius Plantinga argues that the eloquence that can be gained through immersion in literary language - although useful to anyone whose task is rightly handling Scripture - is not the main reason preachers should read literature. Rather, Plantinga says,

The preacher wants his heart stirred because he will then have some idea how the power and the beauty of the gospel might be presented so that the hearts of his brothers and sisters may also be moved. ${ }^{12}$

Not just preachers, but all Christian believers need to have some idea how the power and beauty of the gospel story might be presented - not only to others, but also to ourselves. ${ }^{13}$

\footnotetext{
1 Joseph Bottum, The Decline of the Novel (South Bend, IN: St. Augustine's Press, 2019), 11-12.

2 Karl Ove Knausgaard, "The Slowness of Literature and the Shadow of Knowledge," The New Yorker (November 6, 2019).

3 Marshall McLuhan, The Medium and the Light: Reflections on Religion and Media (Eugene, OR: Wipf \& Stock, 2010), 80.

${ }^{4}$ See, for example, the 2018 survey by the National Endowment for the Arts and the 2018 American Time Use Survey from the U.S. Bureau of Labor Statistics.

${ }^{5}$ Sven Birkerts, The Gutenberg Elegies: The Fate of Reading in an Electronic Age (New York: Farrar, Straus and Giroux, 2006), xiv.

6 Boris Pasternak, Doctor Zhivago (London: Wm. Collins \& Sons, 1958), 75.

7 Graham Ward, "How Literature Resists Secularity," Literature and Theology 24, no. 8 (March 2010), 73-88.

8 C. S. Lewis, An Experiment in Criticism (Cambridge: Cambridge University Press, 2000), 88.

${ }^{9}$ Knausgaard.

10 Rebecca Solnit, "In the Day of the Postman," London Review of Books 35, no. 16 (August 29, 2013).

11 Birkerts, 6.
} 
12 Cornelius Plantinga Jr., Reading for Preaching: The Preacher in Conversation with Storytellers, Biographers, Poets, and Journalists (Grand Rapids: Eerdmans, 2013), 6.

13 [Editor's note:] This article was originally published by Modern Reformation Magazine, Volume 30, Issue 1 (2021), and is republished here with permission. For more information about Modern Reformation, please visit www.modernreformation.org. 